NBER WORKING PAPER SERIES

\title{
THE EFFECT OF THE TAX REFORM ACT OF 1986 ON THE LOCATION OF ASSETS IN FINANCIAL SERVICES FIRMS
}

\author{
Rosanne Altshuler \\ R. Glenn Hubbard \\ Working Paper 7903 \\ http://www.nber.org/papers/w7903 \\ NATIONAL BUREAU OF ECONOMIC RESEARCH \\ 1050 Massachusetts Avenue \\ Cambridge, MA 02138 \\ September 2000
}

This paper was prepared for presentation at the NBER Trans-Atlantic Public Economics Seminar, Gerzenzee, Switzerland, May 22-24, 2000. We are grateful to the International Tax Policy Forum for financial support and to its members for helpful comments and discussions. We thank Kathryn Green for her help with the tax return data. We are grateful to Reuven Avi-Yonah, Bernd Huber, Peter Merrill, Bill Randolph, Don Rousslang, Henry Tulkens, Frank Vella, and seminar participants at the Trans-Atlantic Public Economics Seminar, Michigan State University, Rutgers University, and the American Enterprise Institute for helpful comments. The views expressed herein are those of the authors and not necessarily those of the National Bureau of Economic Research.

(C) 2000 by Rosanne Altshuler and R. Glenn Hubbard. All rights reserved. Short sections of text, not to exceed two paragraphs, may be quoted without explicit permission provided that full credit, including (C) notice, is given to the source. 
The Effect of the Tax Reform Act of 1986 on the Location of Assets in Financial Services Firms

Rosanne Altshuler and R. Glenn Hubbard

NBER Working Paper No. 7903

September 2000

JEL No. H25, H32, H87

\section{$\underline{\text { ABSTRACT }}$}

This paper examines the effects of the Tax Reform Act of 1986 on the international location decisions of U.S. financial services firms. The Act included rule changes that made it substantially more difficult for U.S. firms to defer U.S. taxes on overseas financial services income held in low-tax jurisdictions. These same rule changes were not applied to other forms of income; in particular, income generated from active manufacturing operations was still eligible for deferral after the Act. We use information from the tax returns of U.S. corporations to examine how local taxes affect the allocation of assets held abroad. We find that, before the Act, the location of assets in financial subsidiaries was responsive to differences in host country tax rates across jurisdictions. However, after the Act, differences in host country tax rates no longer explain the distribution of assets held in financial services subsidiaries abroad. In contrast, we find that assets held in manufacturing subsidiaries have become more sensitive to variations in tax rates. Our results suggest that the tightening of the antideferral provisions applicable to financial services companies has been successful in neutralizing the effect of host country income taxes on investment location decisions.

Rosanne Altshuler

Department of Economics

Rutgers University

New Jersey Hall

New Brunswick, NJ 08901-1248

(732)932-7783

altshule@rci.rutgers.edu
R. Glenn Hubbard

Graduate School of Business

Columbia University

609 Uris Hall

New York, NY 10027

(212)854-3493

rgh1@columbia.edu 


\section{Introduction}

The Tax Reform Act of 1986 (hereafter TRA '86) significantly changed the tax environment faced by U.S. firms with operations abroad. One interesting byproduct of the Act is its widening of the gap between the treatment of income earned by financial service subsidiaries of U.S. multinationals and income derived from manufacturing operations. Among other changes, the Act made it substantially more difficult to defer U.S. taxes on overseas financial services income of U.S. firms. In this paper we investigate whether this "tightening" of the anti-deferral rules affected the location of assets held abroad in U.S. financial affiliates.

Under U.S. tax law, income earned by U.S. firms in foreign jurisdictions is subject to U.S. taxation. ${ }^{1}$ However, the active income from foreign operations that are organized as subsidiaries is not subject to U.S. taxation until it is repatriated to the U.S. parent corporation. The ability to defer U.S. tax liabilities on foreign-source income creates incentives for firms to locate operations in low-tax, or tax haven, jurisdictions. The "Subpart F" provisions of the tax code, enacted in 1962, are designed to hamper the ability of firms to avoid U.S. taxes on international income permanently by retaining it abroad in lowtax countries.

As we explain further below, changes made in 1986 to the Subpart F provisions essentially eliminated deferral on active financial services income. These rule changes (which were recently modified for the tax years 1998-2001) were not applied to other forms of active income. As a result, TRA'86 created an environment in which the tax incentive to locate operations in low-tax jurisdictions depends on the "type" of active income the subsidiary is expected to generate. After TRA'86, there is still a tax advantage to locating manufacturing operations in low-tax countries since these operations generate active income that enjoys deferral. However, this tax incentive was greatly diminished for subsidiaries that generate relatively large amounts of active financial services income.

1. See Hines and Hubbard (1995) for a brief summary of U.S. tax policy towards multinational corporations. 
The policy changes in TRA'86 targeted at financial services income provide an opportunity to examine how the location decisions of U.S. multinational corporations respond to taxation. In particular, we use information from the tax returns of U.S. corporations for 1984, 1992, and 1994 to examine how local taxes affect the allocation of assets held abroad in financial services firms before and after the Act. We focus on the hypothesis that, by effectively eliminating deferral on active financial services income, TRA'86 diminished any role played by host taxes in influencing the location decisions of U.S. firms with financial subsidiaries abroad. ${ }^{2}$ Our results are consistent with this hypothesis. We find that, before the Act, the location of assets in financial subsidiaries was responsive to differences in host country effective tax rates across jurisdictions. However, since the Act, the location of assets in these subsidiaries is not sensitive to variations in effective tax rates across countries. Host country effective tax rates no longer explain the distribution of assets held in financial services subsidiaries.

Our results for financial subsidiaries contrast with recent work by Altshuler, Grubert, and Newlon (1998), hereafter AGN, on the mobility of capital in manufacturing subsidiaries. Those authors find that capital in manufacturing subsidiaries has become more sensitive to tax rate differences across foreign jurisdictions in recent years. Although we have a smaller sample than the one used in AGN, our results for the manufacturing subsidiaries in our sample are qualitatively similar. ${ }^{3}$ We also find that capital held in manufacturing subsidiaries has become more responsive to variations in effective tax rates across countries.

We estimate tax elasticities of assets that control for unmeasured country fixed effects. We find that fixed country effects play a large role in explaining differences in the stock of assets in financial services affiliates across jurisdictions. Our results suggest that policymakers should not rely solely on

2. Other provisions of TRA'86 also have the effect of decreasing the importance of local tax rates for the location of assets in financial subsidiaries. These rule changes, which modify the calculation of the tax credit U.S. firms are allowed against U.S. tax liabilities for taxes paid to host countries, are discussed in section two.

3. As we explain further below, our sample includes manufacturing affiliates of all U.S. parents. AGN focus on manufacturing affiliates of manufacturing parents. We were unable to obtain this level of detail from the Internal Revenue Service. 
simple cross-sectional estimates of the responsiveness of financial assets to tax rate differences when asking questions concerning the role of taxes in the location decisions of this industry.

For the financial services industry, the changes embedded in TRA'86 moved the U.S. tax system closer to one in which "capital export neutrality" is preserved for investments in low-tax countries. Capital export neutrality holds when investors pay the same level of taxes on investment projects regardless of where they are undertaken. Our results suggest that, as intended, TRA'86 decreased the importance of local taxes in the location decisions of financial services firms. While manufacturing firms can continue to exploit differences in effective tax rates to minimize tax liabilities, financial service firms have much less latitude to do so.

An open question is the extent to which TRA'86 has impacted the competitiveness of U.S. financial service firms who must compete for international market share with subsidiaries of firms from countries in which foreign-source income is exempt from taxation ("territorial" tax systems). Previous research on the impact of TRA'86 on the operations of the financial services industry abroad has, for the most part, focused on how the Act affects hypothetical U.S. firms (see Horst 1997; Dunahoo, Lyon, and Merrill, 1997; and PricewaterhouseCoopers, 1998).

Horst (1997) calculates the effective tax rate in a low-tax country faced by a hypothetical subsidiary in the property and casualty insurance business. He contrasts the effective tax rates faced by subsidiaries with parents in the U.S. with effective tax rates that might be faced by subsidiaries with home bases in other foreign countries. ${ }^{4}$ He finds effective rates of taxation for affiliates with U.S. parents that are as much as 145 percent higher than those faced by affiliates from other countries. ${ }^{5}$ These higher

4. The countries are Switzerland, the Netherlands, Belgium, Hong Kong, Japan, the United Kingdom, Germany, France, Denmark, Sweden, and Canada. Horst points out none of these countries applies current taxation to the active business income of subsidiaries in the financial services sector.

5. This calculation assumes that the affiliate is located in a host country with an effective tax rate of 14.3 percent. The total tax on the affiliate depends on the size of the tax (if any) imposed by the resident country on the income earned in the host country and when it is imposed. Prior to TRA' 86 , the U.S. affiliate would not have been liable for any residual U.S. tax on (active) income until the income was repatriated. Under TRA'86, the U.S. affiliate is taxed an additional 20.7 percent on the income earned in the host, regardless of whether it is repatriated. This residual tax liability raises the U.S. tax burden to the U.S. tax rate of 35 percent $(14.3+20.7)$. Of the eleven 
effective tax rates are mainly the result of the 1986 changes to the Subpart F rules that eliminate deferral of U.S. tax on active financial services income.

Dunahoo, Lyon, and Merrill (1997) focus on the total tax burden of a hypothetical life insurance subsidiary incorporated abroad. They also find that the Subpart F rules under which certain financial services income is currently taxed may have important effects on the competitiveness of U.S. multinational corporations. ${ }^{6}$ In their example, a life insurance subsidiary with a U.S. parent faces a total tax burden that is 24.1 percent greater than an identical subsidiary with a French, German, Dutch, or British parent.

While suggestive, this research has not uncovered whether the competitive position of U.S. firms in the financial services industry has changed due to the Act. ${ }^{7}$ This is most likely because data on the market share of U.S. and foreign financial services firms in host country markets (low-tax countries, in particular) from before and after TRA' 86 is necessary to address the competitiveness issue. We were unable to locate a set of data rich enough to include market share information over the required time period for both U.S. financial services affiliates and affiliates of parents incorporated in "territorial" countries (or any other country that does not apply current taxation to active financial services income). Instead we focus on whether moving the tax system towards capital export neutrality has had any impact on the role played by taxes in the location of assets in financial services subsidiaries abroad.

In this respect our work is similar to that of Desai and Hines (1999), who examine the impact of TRA'86 on the joint venture activity of U.S. corporations. The Act made changes to the rules governing the calculation of the foreign tax credit which reduced the attractiveness of investing in international joint ventures, particularly those located in low-tax jurisdictions abroad. Desai and Hines provide evidence that countries examined, the affiliates of four (France, Switzerland, Belgium, and Hong Kong) face no additional home country tax. The remaining hypothetical affiliates face additional resident country taxes ranging from 1.4 percent (in Sweden) to 6.6 percent (in Japan).

6. These calculations (and the ones in Horst, 1997) are made in the absence of the one-year exception from Subpart F enacted in 1997 and extended (and modified) in 1998 and 1999. We discuss these new provisions below.

7. An exception is a study of the shipping industry by Price Waterhouse (1997). Under TRA'86, all foreign shipping income is subject to current U.S. taxation (an exception for shipping income reinvested in qualified shipping assets was available from 1975 to 1986). The Price Waterhouse study finds that the U.S. owned share of the world's shipping fleet declined from 26 percent in 1975, to 14 percent in 1986, to only five percent in 1996. 
U.S. participation in joint venture abroad fell substantially after 1986 . To test whether the pattern of joint venture activity across countries was consistent with the tax incentives created by TRA' 86 , they compare changes in measures of business activity in minority-owned U.S. affiliates abroad (joint ventures) before and after the Act with similar data for majority-owned U.S. affiliates abroad. ${ }^{8}$ Majority-owned affiliates are a natural comparison group for this policy experiment because the provisions in TRA' 86 affecting the foreign tax credit calculation of joint ventures did not apply to this organizational form. The results in Desai and Hines, derived from U.S. Commerce Department data, provide strong evidence that the organization of U.S. business abroad is sensitive to changes in the U.S. tax treatment of international income.

The remainder of the paper is organized as follows. Section 2 contains a brief legislative history of the anti-deferral (Subpart F) regulations along with a discussion of other tax law changes in TRA'86 affecting the financial services sector. Section 3 discusses the methodology we use to measure the sensitivity of location decisions to effective tax rates and describes the tax return data. Our results are presented in section 4. The final section concludes and offers suggestions for future research.

\section{A Brief Legislative Review}

To place the provisions of the Tax Reform Act we study in context, we begin with a brief overview of the pertinent U.S. tax rules. We start with the basics before moving on to the specific changes to the Subpart F provision that are the focus of the paper. U.S. multinationals are taxed on income earned both inside and outside the United States. To prevent income earned abroad from being taxed twice, the U.S.

${ }^{8}$. Desai and Hines (1999) measure the impact of local tax rates on changes in equity holdings, royalty payments, and leverage ratios in joint ventures and majority-owned affiliates between 1982 and 1989. The changes in the rules for calculating foreign tax credits enacted with TRA' 86 increased the cost of equity capital in joint ventures relative to majority-owned affiliates and, consequently, increased the attractiveness of transferring technology and debt to overseas affiliates particularly in low-tax jurisdictions. Consistent with the tax incentives created by TRA'86, they find that local tax rates have a positive and significant effect on the difference in growth rates in equity holdings between minority- and majority-owned affiliates, a negative and significant effect on the change in royalty payments, and a negative and significant effect on the change in leverage ratios. 
allows firms to claim foreign tax credits for income taxes paid to foreign governments. These tax credits can be used to offset U.S. tax liability on foreign-source income. For example, suppose a multinational corporation earns $\$ 100$ in a country with a 25 percent tax on corporate profits while the current corporate tax rate in the U.S. is 35 percent. Under the foreign tax credit system, the multinational is allowed to credit the \$25 tax paid to the foreign government against the \$35 owed to the U.S. government, leaving a residual U.S. tax liability of $\$ 10$ on the $\$ 100$ of foreign-source income.

A limitation on the credit prevents U.S. firms from using foreign tax credits to reduce U.S. tax liabilities on income earned at home. The limit is the amount of tax that would be due if the foreign income were earned in the U.S. Suppose now that the multinational earns $\$ 100$ in a country with a tax rate of 45 percent. Since the U.S. tax rate is 35 percent, the foreign taxes paid (\$45) exceed the U.S. tax liability (\$35) on the $\$ 100$ of foreign-source income. A firm in this situation is said to be in an "excess credit" position because it has more foreign tax credits than can be claimed in the current year. ${ }^{9}$ The same firm would be said to be in an "excess limitation" position if it had earned the $\$ 100$ in a country with a tax rate below the U.S. rate.

In some situations, the foreign tax credit system allows firms to use excess credits from one source of foreign income to offset U.S. tax payments on income from another source - a procedure known as "cross-crediting" or "averaging." To understand how cross-crediting works, we assume that the multinational firm earns $\$ 100$ in each country --- the low-tax country with a tax rate of 25 percent and the high-tax country with a tax rate of 45 percent. Cross-crediting allows the U.S. parent corporation to offset the $\$ 10$ of U.S. tax liability on the $\$ 100$ repatriated from the low-tax affiliate against the $\$ 10$ of excess credits on the $\$ 100$ repatriated from the high-tax affiliate. As a result, no residual U.S. tax is due on the \$200 of foreign-source income. Firms may only average income of the same type of "basket" for the

9. Under current law, excess credits can be carried back to offset any U.S. tax payments on foreign-source income made in the previous two years. Credits may also be carried forward without interest and used to offset U.S. tax liability in the following five years. 
purpose of the foreign tax credit; as we explain below, averaging is allowed within baskets, but not across baskets.

The time at which the U.S Treasury taxes foreign profits depends on how the multinational has organized its foreign operations. If those operations are organized as subsidiaries (they are separately incorporated in the foreign country), then the profits are not generally taxed until they are paid to the U.S. parent corporation. The profits of foreign operations organized as branches (they are not separately incorporated in the foreign country) are taxed upon accrual.

Prior to the Revenue Act of 1962, multinationals enjoyed deferral on all classes of foreign-source income earned by foreign subsidiaries (with the exception of income earned in foreign personal holding companies). The Revenue Act created the Subpart F provisions in an effort to hamper the ability of firms to avoid U.S. taxes on foreign income by retaining it abroad in low-tax jurisdictions. ${ }^{10}$ In general, these "anti-tax avoidance" provisions deny deferred taxation on foreign subsidiary income that is considered abusive. The original provisions impose accrual taxation on certain "passive" income such as that income earned from investments in financial assets, foreign base company sales and services income, and income derived from the insurance of U.S. risks. Income from active business investments abroad continued to enjoy deferred taxation.

Since the Subpart F provisions were enacted in 1962, Congress has expanded their scope to include additional types of foreign subsidiary income. The Tax Reduction Act of 1975 disallowed deferral on shipping income that was not reinvested in shipping assets. ${ }^{11}$ The Tax Equity and Fiscal Responsibility of 1982 expanded Subpart F to include foreign oil-related income.

10. The Subpart F rules were the outcome of a debate on whether to entirely eliminate deferral. Congress supported deferral, the administration supported accrual taxation. Since 1962 there have been numerous proposals to end deferral. See Appendix A of Hufbauer (1992) for a short history of deferral in the U.S. tax system. See also Hubbard (1995), National Foreign Trade Council (1999), and Hines (1999b) for a review of more recent policy debates about deferral.

11. This act also eliminated deferral of passive income earned in tax haven countries by repealing the safe harbor minimum distribution rules in Subpart F. Income from countries participating in Arab League boycotts was denied deferral in 1976. See Hines (1995) for an analysis of the impact of the boycott provisions on U.S. operations in Arab League countries. 
TRA'86 substantially eroded the ability of financial services firms to defer foreign-source income by incorporating within Subpart F additional categories of both passive and active income. The Act's provisions terminated deferral on dividends and interest earned by financial services subsidiaries regardless of whether the income was generated from the conduct of active business, on third-party insurance income, and on shipping income regardless of whether it was reinvested in shipping assets. To a large extent, TRA'86 eliminated deferral on foreign financial services income. At the same time, U.S. multinationals generating active (nonfinancial) income through manufacturing affiliates were not affected by the Act's expanded Subpart F provisions.

The tightening of the anti-deferral rules led to a substantial increase in the amount of Subpart F income reported. Latzy and Miller (1992) use tax return data to examine the growth of Subpart F income claimed by controlled foreign corporations (CFCs) of U.S. parent corporations between 1986 and $1988 .{ }^{12}$ They found that the largest 7,500 CFCs (in terms of asset size) reported Subpart F income of over $\$ 12$ billion dollars in 1988, which represents an increase of almost $\$ 8$ billion dollars over the 1986 level. In addition, the number of large CFCs that recorded any Subpart F income nearly doubled (from 11 percent in 1986 to almost 22 percent in 1988). As a percentage of total (positive) earnings and profits, Subpart F income increased from 10 percent to 19 percent over this time period which suggests that "... an increasing amount of the undistributed earnings of CFCs are now subject to current U.S. taxation (page 64)."13

TRA'86 represented a major overhaul to the U.S. tax system and, as such, included other important provisions for the taxation of foreign-source income. The Act lowered the corporate tax rate from 46 to 34 percent and at the same time broadened the tax base through modifications of depreciation schedules and the repeal of the investment tax credit. All else being equal, the lower corporate tax rate would be expected

12. A CFC is a foreign corporation that is at least 50 percent owned by a group of U.S. shareholders each of whom have at least a 10 percent interest in the company.

13. The increase in Subpart F income, number of CFCs claiming Subpart F income, and Subpart F income as a percentage of positive earnings and profits was not limited to CFCs incorporated in tax haven countries. See Latzy and Miller (1992) for details. 
to shift multinationals toward excess credit positions, leaving firms with no additional tax liabilities to the U.S. Treasury on income repatriations from abroad. Interestingly, the United States did not become a "low-tax" country; tax rates in many capital importing countries were lowered after the imposition of the Act. ${ }^{14}$ Grubert, Randolph, and Rousslang (1996) find that in 1992 only 35 percent of foreign source income was received by U.S. multinational corporations with excess credits which is comparable to the 33 percent of foreign source income received by such firms in 1984. Their analysis of Treasury tax return data shows a substantial decrease in average effective tax rates on repatriated income that they conclude is primarily due to reductions in country average tax rates.

As with the modifications to the Subpart F rules, changes to the foreign tax credit limitation embedded in TRA'86 impacted parent corporations with financial services subsidiaries and manufacturing subsidiaries differentially. Prior to the Act, there were six separate foreign tax credit baskets: (1) passive interest income, (2) domestic international sales corporation (DISC) dividend income, (3) foreign sales corporations (FSC) dividend income, (4) foreign trade income of a foreign sales corporations, (5) oil and gas extraction income, and (6) all other foreign-source income. The goal of the basket system is to separate income that bears extremely high foreign taxes from income of a different type or category that bears little or no foreign tax. TRA'86 expanded the number of baskets, decreasing the potential to average for the purpose of the foreign tax credit, particularly so for financial income. ${ }^{15}$ The new baskets include one for high-withholding-tax interest income, an expanded passive income basket that captures passive income generally (not just interest income), a separate basket for financial services income, a separate basket for

${ }^{14}$. Along with lowering corporate tax rates, some countries have enacted $\mathrm{CFC}$ rules that subject certain foreign source income to current taxation since the passage of TRA'86. Two examples are Australia and New Zealand. For further discussion see OECD (1996), Grubert (1997), and National Foreign Trade Council (1999).

${ }^{15}$. As explained in the Joint Committee on Taxation's General Explanation of the Tax Reform Act of 1986, "A separate or special limitation generally is applied to a category of income for one of three reasons: the income's source (foreign or U.S.) can be manipulated; the income typically bears little or no foreign tax; or the income often bears a rate of foreign tax that is abnormally high or in excess of rates on other types of income. Applying a separate limitation to a category of income prevents the use of foreign taxes imposed on one category of income to reduce the U.S. tax on other categories of income.” (page 856) 
shipping income and a separate basket for the dividends of each noncontrolled (between 10 and 50 percent) foreign corporation. ${ }^{16}$

Why were financial services firms singled out by TRA'86? One theme in the Joint Committee on Taxation's General Explanation of the Tax Reform Act of 1986 is that foreign financial income is highly mobile and consequently the choice of location is very sensitive to variation in tax rates. Congress believed that the types of income targeted for inclusion in Subpart F “...could sometimes be earned through a foreign corporation in a tax haven countries that bears limited substantive economic relation to the income and that allowing continued deferral of U.S. tax on this type of income could encourage the movement of the associated operations abroad at the U.S. Treasury's expense (page 965).” The current taxation of this foreign income is meant to move the tax system closer to one in which the multinational firm faces the same effective rate of tax on its investment regardless or whether it is undertaken at home or abroad. The availability of deferral for a much broader range of active income moves the tax system away from this criterion (capital export neutrality) for manufacturing firms. Given the tax rule changes in TRA'86, holding other things constant, the location of manufacturing capital should therefore be more sensitive to differences in tax rates across foreign jurisdictions than the location of assets generating financial services income.

Our argument that TRA'86 moved the tax system closer to one in which capital export neutrality is preserved for the financial services sector ignores the Act's changes to the foreign tax credit limitation and their impact on the ability of firms to cross-credit. As with the changes to the Subpart F rules, the increase in baskets was motivated by a concern that income generated from financial assets could be easily shifted and, in this case, used to absorb excess credits from unrelated highly taxed business operations. Congress was also concerned that, on balance, cross-crediting created a situation in which foreign investment was

16. Recent legislation passed in 1997 eliminated the separate baskets for noncontrolled (between 10 and 50 percent) corporations. Under the new law, which takes effect in 2003, parents will be able to average all dividend income from noncontrolled ("10-50") corporations into one basket for the purpose of the foreign tax credit. 
favored over U.S. investment. ${ }^{17}$ Allowing for cross-crediting can move the tax system closer to or further from capital export neutrality depending on the foreign tax credit position of multinational corporations. ${ }^{18}$ Parent firms in excess limitation positions are indifferent between investments at home and in low-tax countries abroad since (ignoring deferral) they face the same tax rate at home and abroad. Multinationals in excess credit positions, however, prefer investments in low-tax locations over investments in high-tax locations, since excess credits absorb any residual tax owed to the U.S. government on income repatriated from low-tax jurisdictions.

Increasing the number of separate limitation baskets makes cross-crediting more difficult and, along with the changes to the Subpart F provisions, can move the tax system towards capital export neutrality. ${ }^{19}$ To see this, consider two groups of parent corporations in the financial sector --- one group with excess credits in the pre-TRA' 86 basket that contained financial services income and one group in excess limitation. Adding a separate basket for financial services income makes it difficult for the firm with excess credits in the pre-TRA'86 basket to absorb residual tax liabilities from investments generating lightly taxed income (investments in low-tax countries, for example). This is because after TRA'86, the lightly taxed income would generally be in a separate basket and therefore cannot be averaged with hightax income to reduce U.S. tax liabilities. As a result, these parent firms will no longer favor low-tax investments over investments at home or in high-tax countries. Parent firms in excess limitation face capital export neutrality for low-tax investments both before and after TRA'86. Taken together, both the

17. See, for example, U.S. Congress (1987, page 862).

18. See, for example, the discussion in Altshuler and Newlon (1993) and Cummins and Hubbard (1995).

19. As we noted earlier, Desai and Hines (1999) investigate whether the imposition of separate limitation baskets for noncontrolled CFCs (10-50 corporations) affected the activities of U.S. multinationals in low-tax jurisdictions. As is the case with the separate basket for financial services income, the separate baskets for 10-50 corporations decrease the attractiveness of setting up operations in low-tax countries. Desai and Hines find that U.S. participation in 10-50 corporations fell substantially after 1986, particularly in low-tax jurisdictions. 
changes to the anti-deferral laws and the foreign tax credit arguably move the system closer to capital export neutrality for the financial services sector. ${ }^{20}$

Recent legislation has included some important changes to the Subpart F rules enacted in TRA'86.

The path to enactment for these new laws was a bit bumpy. The Taxpayer Relief Act of 1997, as

originally passed by Congress, contained an exemption from Subpart $\mathrm{F}$ for the active financing income of insurance companies, banks, and securities firms. ${ }^{21}$ President Clinton eliminated the exception from the tax package by exercising his line-item veto authority. The provision was later reinstated after the Supreme Court found the Line-Item Veto Act unconstitutional. The Supreme Court ruling was made in June, only days before the Joint Committee on Taxation published their list of extensions to the Taxpayer Relief Act of $1997 .{ }^{22}$ Due to the timing of the decision, the one-year exception was included on the list and was available for the 1998 taxable year. A new version of the temporary exemption was included in the omnibus spending package of 1998. As before, the modified exception applies only for one year (the taxable year beginning in 1999). Legislation passed in 1999 extended the exception for tax years beginning before January 1, 2002. The latest incarnation of the Subpart F exception contains some different tests for determining whether income derived from the active conduct of a financial services business qualifies for

20. To see this, divide parent firms into four groups depending on their foreign tax credit status (in the active basket) before and after the Act. Firms in excess limitation before and after TRA' 86 are discouraged from investing in low-tax countries (relative to before the Act) since they can no longer defer active income there. Firms that transit from excess credit to excess limitation positions move closer to capital-export neutrality since they lose deferral and averaging opportunities. Firms in excess limitation before TRA' 86 but in excess credit after TRA' 86 may also face reduced incentives to invest in low-tax jurisdictions if income generated there ends up in new baskets with other lightly taxed income. Finally, firms in excess credit before and after TRA' 86 may also be discouraged from investing in low-tax countries for the same reasons. Because the tax return data available publicly is aggregated by country, we are unable to divide our analysis according to parents' credit positions before and after the Act. With parent-level data we could separately examine the first two sets of firms for which incentives to invest in low-tax countries decreased the most.

21. The exception from Subpart $\mathrm{F}$ was for income that is derived in the active conduct of a banking, financing, or similar business by a CFC that is predominantly engaged in the active conduct of such business. The exception also applied to certain investment income of a qualifying insurance company with respect to risks located within the CFCs country of creation or organization. The exception did not apply to investment income allocable to contracts that insure related party risks or risks located in a country other than the country in which the qualifying insurance company is created or organized.

22. See Dehoff (1998) for a discussion of the history and content of the 1997 and 1998 exemptions. 
deferral and more stringent anti-abuse rules. Whether these exceptions have any impact on the location decisions or market share of U.S. financial service firms is a question for future evaluation.

A growing body of research has investigated the extent to which multinational firms respond to changes in the tax environment they face (see, e.g., the reviews in Hines 1997 and 1999a) and empirical evidence supports the idea that tax policy plays an important role in the economic decisions of multinational corporations. However, most of the previous research has not focused on the impact of TRA'86 (or previous tax changes) on the behavior of financial services firms. The changes to Subpart F for these firms were predicated on the belief that the activities and investments of these firms were highly mobile and therefore very sensitive to tax differences across jurisdictions. A natural question to ask is whether there is any evidence that differences in host country tax rates explain the distribution of assets of financial services firms abroad. A more precise way of asking this question is to pose it in terms of a measure of sensitivity: How responsive is the location of assets in financial services affiliates to differences in host country tax rates?

As we explained above, TRA'86 moved the system closer to capital export neutrality (with respect to investments in low-tax locations) for financial services firms. As a result, if firms are sensitive to differences in effective tax rates, we may explore whether this sensitivity has diminished after TRA'86. In other words, has the location of assets in financial services firms become less responsive to host country taxes? AGN address these questions in their analysis of the location of real capital held in the manufacturing affiliates of U.S. manufacturing parent firms. ${ }^{23}$ We focus instead on firms in the financial services sector.

AGN use data from the U.S. Treasury tax return files for 1984 and 1992 to estimate the responsiveness of direct investment abroad to after-tax rates of return. Unlike previous studies, these researcher's access to more than one year of cross-sectional data allowed them to estimate tax elasticities

23. Grubert and Mutti (1991, 1997) and Hines and Rice (1994) also study the responsiveness of location decisions to taxes, but not whether estimated tax elasticities have increased over time. 
that control for fixed country effects. They focus on the allocation of real capital abroad by manufacturing affiliates of U.S. manufacturing parents and find evidence that it has become more sensitive to differences in effective tax rates across host countries over their sample period. Their estimates with country fixed effects yield an elasticity of real capital to changes in after-tax rates of returns of 2.8 in 1992 and 1.5 in 1984. ${ }^{24,25}$ Both the point estimates and the difference between them are statistically significantly different from zero at standard confidence levels. This work suggests that the influence of taxes on location decisions has become more pronounced. To preview our results, using information from the same data source as AGN, we find evidence that TRA'86 may have led to a decrease in the mobility of assets for financial services firms. ${ }^{26}$

\section{The Data}

The data were provided to us by the Statistics of Income (SOI) division of the Internal Revenue Service. ${ }^{27}$ SOI collects information from a number of tax and information forms filed by U.S. multinational corporations. We requested information from the Form 5471, which reports on the activities of each CFC of a U.S. parent. This form contains subsidiary level information on assets, taxes paid, earnings and profits, and other information from balance sheets and income statements. We obtained information on total CFC assets (cash, inventories, buildings and other depreciable assets, land, loans to stockholders and

24. Grubert and Mutti (1997) and AGN include a measure of trade restrictions as an explanatory variable in their regression models so the elasticity estimates reported above are for countries with the most open trade regimes (for which the trade restriction variable is zero). Adjusting the 1992 elasticity, for example, by trade regime (using 1992 real capital stocks as weights) gives a slightly lower tax elasticity of 2.64 .

25. The 1992 open economy elasticity is similar in magnitude and significance to the estimates in Grubert and Mutti (1997). Their study used both aggregate country-level data and firm specific data from the 1992 Treasury tax files.

${ }^{26}$. Neither this study nor AGN analyzes the effect of taxes on the choice of investing at home or abroad. Our empirical models focus instead on the choice of investment locations across foreign jurisdictions.

${ }^{27}$. The data were provided in response to a special data request that was necessary to obtain information by industry. 
related persons, investment in subsidiaries, and intangible assets), real CFC assets (inventories, buildings, and other depreciable assets), earnings and profits before income taxes, and income taxes. ${ }^{28}$

The data provided to us by SOI are aggregated across CFCs by country and are partitioned by the industry of the CFC; we have separate data for CFCs in the finance, insurance, and real estate sector (FIRE) and for CFCs in the manufacturing sector. ${ }^{29}$ This industry detail allows us to compare changes in the sensitivity of location decisions to taxes of assets held in manufacturing and financial subsidiaries abroad. We use data from the same years as AGN --- 1984 and 1992 --- and more recent tax return data for $1994 .{ }^{30}$ We supplemented the data with information on gross domestic product from the International Monetary Fund International Financial Statistics. ${ }^{31}$ Our dataset for financial CFCs of U.S. parents contains complete information for 32 countries for the three years of analysis. Our dataset on manufacturing CFCs of U.S. parents contains complete information for 40 countries.

We use simple ordinary least squares to estimate the elasticity of assets to after-tax rates of return as in Grubert and Mutti (1991) and other studies. The after-tax rate of return is simply (1-ETR), where ETR equals the country average effective tax rate. The basic estimating equation is thus:

$$
\log \left(\operatorname{Assets}_{i t}\right)=\alpha_{i}+\beta_{1} \log \left(1-\mathrm{ETR}_{i t}\right)+\beta_{2} \log \left(\mathrm{GDP}_{i t}\right)+\varepsilon_{i t},
$$

28. Corporations are required to report the historical book value of assets according to U.S. accounting principles. As AGN notes, this reporting standard prevents the asset figures from being distorted by host country investment incentives. However, host country inflation and exchange rates could affect the measures. Another problem with the asset measures in the SOI data involves the actual location of the assets reported. CFCs report assets based on their country of incorporation. However, the country of incorporation may not be where the capital is actually located. Grubert and Mutti (1997) were able to use additional data, not available in our file, to classify the real assets in their sample by the CFCs principal place of business (firm's include this information on the Form 5471) instead of by the CFC's country of incorporation. The reclassification had little effect on their results (only 2 percent of real assets were affected).

29. The 1984 sample includes all U.S. parent corporations with at least one CFC and total assets greater than $\$ 250$ million in assets. All U.S. corporations with at least $\$ 500$ million in assets were included in the 1992 and 1994 samples. However, the 1992 and 1994 samples contain information only for the top 7,500 CFCs in terms of asset size. These CFCs account for 94 percent of assets "controlled" by all CFCs of U.S. multinational corporations with at least \$500 million in assets in 1992 and 1994.

${ }^{30}$. Information from the Form 5471 is compiled only in even years.

${ }^{31}$. In a few cases information on GDP was not available from the IMF statistics. In these cases we used information from the United Nations. 
where $i$ subscripts countries and $t$ subscripts years, ETR is the country effective tax rate, and GDP is gross domestic product. GDP can be interpreted as a "scale" variable that reflects the economic size of countries. The estimated coefficient on the tax term, $\beta_{1}$, gives the (constant) elasticity of assets to changes in after-tax returns (for a given pre-tax return). This reduced-form relation between after-tax returns and investment is consistent with a partial equilibrium model in which firms allocate assets abroad to maximize after-tax returns to investment.

A difficult issue in estimating this type of location equation involves the appropriate choice of local tax rates. Researchers have debated the merits and drawbacks of using statutory corporate tax rates, marginal local effective tax rates, average local effective tax rates, and effective tax rates that include the impact of home country repatriation taxes to measure the incentive effect of taxes on location choices (see the empirical studies of taxes and location decisions reviewed in Hines (1997), or more recently, see Grubert and Mutti (1997) and AGN). We use country average effective tax rates in our empirical work for a variety of reasons. First, even if appropriate, marginal effective tax rates on income generated in financial and manufacturing operations abroad are not available for all of the years and countries in our sample. Second, statutory rates are unlikely to reflect the tax treatment of investments in different countries since they do not capture special incentives for different industries and/or different firms within countries. Subsidiaries involved in manufacturing, for example, often receive tax incentives in the form of tax holidays. These tax incentives may depend on the location of the subsidiary and may expire after some years. Subsidiaries in the financial sector are also likely to face tax rules that result in tax burdens that do not correspond to statutory tax rates. Calculating an average effective tax rate across all subsidiaries by industry will take into account the special provisions and tax incentives faced by firms in the different industries in each country. Finally, although our use of host country average effective tax rates ignores the impact of home country repatriation taxes on location decisions, we feel the choice is an appropriate one 
for our analysis. Our hypothesis is that after TRA'86, the location of assets in financial subsidiaries should be less responsive to differences in host country tax rates across jurisdictions.

We calculate country average effective tax rates for financial and manufacturing CFCs by dividing total income taxes paid by total earnings and profits before income taxes. Only those CFCs with positive earnings and profits before taxes are included in the calculation to prevent the tax rate measure from being biased upwards. We do not include other taxes that may be imposed in host countries, such as property and assets taxes, because this information is not available in our data.

Tables 1 and 2 contain country average effective tax rates for the financial and manufacturing subsidiaries in our sample, respectively. We present country effective tax rates for 1984 and for the early 1990s, calculated as the average of the 1992 and 1994 country effective tax rates. Effective tax rates have declined significantly since $1984 .^{32}$ Averaged over all countries, effective tax rates faced by both financial and manufacturing subsidiaries abroad have fallen by more than 10 percentage points during the ten-year period spanned by our study. As a percentage of the 1984 rate, effective tax rates fell more for financial subsidiaries (47 percent) than for manufacturing subsidiaries (33 percent) between 1984 and the 1990s. Comparing effective tax rates across the two industries shows that financial subsidiaries generally face lower rates than manufacturing subsidiaries. On average, the financial effective tax rates are about 80 percent of the manufacturing rates (87 percent in 1984, 63 percent in the 1990s). ${ }^{33}$ However, these averages mask a substantial variation between the ratios of financial to manufacturing effective tax rates. The standard deviation of the ratio ranges from between 80 percentage points in 1984 to 50 percentage points in the 1990s. ${ }^{34}$ In each period effective tax rates for financial subsidiaries exceeded effective tax

32. This is consistent with the pattern shown in Table 1 of AGN, where estimated average effective tax rates for manufacturing declined from 0.321 in 1980 to 0.234 in 1992.

33. The average of manufacturing effective tax rates as a percentage of financial effective tax rates for 1984 does not include Argentina, which had an extremely low effective tax rate for manufacturing subsidiaries in that year. ${ }^{34}$. The standard deviation of the ratio between financial and manufacturing effective tax rates is 80.5 percentage points in 1984. These statistics are not reported in the tables. 
rates for manufacturing subsidiaries in a small set of locations (five countries in 1984 and nine countries in the 1990s).

There are some drawbacks to using these average effective tax rates in our empirical analysis. First, in some cases they are based on observations from a small number of subsidiaries. This likely adds noise to our tax rate measures. In addition, at an individual firm level, these tax rates are endogenous to investment decisions. Averaging across all CFCs in a country should diminish this relation to some extent. ${ }^{35}$ However, we take some steps to investigate and ameliorate these problems in our empirical tests.

Although the focus of previous studies has been on the location of real capital abroad, our emphasis on the behavior of multinational corporations with financial subsidiaries suggests that we should examine the relation between taxes and the placement of total, as opposed to real, assets. In Table 3 we provide information on the ratio of real to total assets in our two groups of CFCs. Because these ratios differed little over the sample period, we report the ratio, averaged over all three years, of real to total assets for each country. Real assets account for a very small percentage of total assets in financial affiliates (less than eight percent on average). Assets held in manufacturing affiliates of U.S. parents, on the other hand, are comprised mainly of real assets (62 percent of total assets on average). These ratios suggest that the appropriate measure of assets in the financial sector regressions should be total assets and that real assets should be used in the manufacturing equations.

\section{Empirical Evidence on Tax Sensitivity}

Instead of running cross-sectional regressions on each of the three years of data, we start by pooling the data. This allows us to test whether the tax elasticity $\left(\beta_{1}\right)$ has changed over time. ${ }^{36}$ To do this,

35. Simply using average effective tax rates over all subsidiaries in a country does not eliminate the endogeneity problem. Effective tax rates may be low in a country in a given year because of an increase in investment qualifying for tax incentives in that year.

${ }^{36}$. We also tested whether the coefficient on $\log (\mathrm{GDP})$ should be constrained to be the same in the three years. An F-test fails to reject the constrained model in both the pooled model (first column) and the fixed effects model (second column). 
we introduce additional terms (a year dummy and an interaction term) to equation (1) to produce separate estimates of the tax coefficient for each sample year. In particular, we include the following variables to the model in equation (1):

$\log (1-\mathrm{ETR}) *$ Year92, $\log (1-\mathrm{ETR}) *$ Year94, Year92, and Year94. Year92, for example, is an indicator variable that equals one if the observation is from 1992, and equals zero otherwise. The coefficient on the interaction term, $\log (1-\mathrm{ETR}) *$ Year92, estimates the difference between the 1984 elasticity and the 1992 elasticity.

Our principal results for financial subsidiaries are reported in Table $4 .{ }^{37}$ The estimated tax elasticities for each year are reported in the bottom panel of the table. ${ }^{38}$ The first column presents the estimation results for the pooled regression. These estimates suggest that total assets held in subsidiaries are quite sensitive to differences in after-tax returns across jurisdictions. The tax elasticities for all of the sample years are large and statistically significantly different than zero. Furthermore, neither the 1992 nor the 1994 estimated elasticity is significantly different from the 1984 estimated elasticity (the coefficients on the interaction terms, $\log (1-\mathrm{ETR}) *$ Year92 and $\log (1-\mathrm{ETR}) *$ Year94, are not statistically significantly different from zero). Assets held in financial subsidiaries appear highly responsive to variations across jurisdiction in effective tax rates both before and after TRA'86. The elasticity estimates suggest that a one percent increase in after-tax returns leads to an increase in the total capital stock held by U.S. subsidiaries of between six and eight percent.

Cross-country variation in average effective tax rates may be correlated with unobserved differences in countries that affect their attractiveness for investment. As a result, the estimated effect of the tax term may reflect both tax and non-tax factors on investment decisions. One way of controlling for

37. See the Appendix table for means and standard deviations of the variables used in these regressions.

38. The tax elasticity estimates and standard errors for each year are estimated by running analogous regressions with different year dummies and interaction terms. For instance, to estimate the 1992 elasticity in the second column of Table 4, we replace the 1992 dummy with a dummy for 1984 (Year84) and the 1992 tax interaction term with $\log (1-\mathrm{ETR}) *$ Year84. The coefficient on $\log (1-\mathrm{ETR})$ in this new regression gives the estimated 1992 tax elasticity and associated standard error. 
persistent unobserved differences across countries is to add country dummy variables to the right-hand side of equation (1).

The results from this country fixed-effects specification are presented in the second column of Table 4. These estimates suggest that, for financial subsidiaries, variation in effective tax rates across countries is correlated with country characteristics. The tax coefficients are reduced in both size and statistical significance. In fact, the estimated 1992 and 1994 tax elasticities shown in the lower panel are negative in the second column and no longer statistically significantly different from zero. The coefficients on the interaction terms are statistically significantly different from zero (at the 10 percent confidence level), suggesting that assets have become less sensitive to differences in effective tax rates across locations since 1984. The estimated 1984 tax elasticity is still statistically significantly different from zero at conventional levels of significance, but the magnitude of the estimated coefficient is less than half of the estimate from the first column.

The statistically insignificant coefficients on the year dummies in the second column (as well as the first column) indicate that it is not necessary to allow the intercept in our regression equation to vary across years and an F-test accepts the exclusion of the year dummies. We present results that exclude the year dummies from the country-fixed-effects regression in the third column of Table 4. Except for the estimated coefficient on $\log (\mathrm{GDP})$, the estimates from the specifications in the second and third columns are similar. However, dropping the year dummies does increase the magnitude of the coefficients on the tax and interaction tax terms. In particular, the estimated 1984 tax elasticity and the difference between the 1984 and 1992 and 1994 estimated tax elasticities are statistically significantly different from zero at a two percent confidence level.

In model presented in the fourth column of Table 4, we constrain the 1992 and 1994 tax elasticities to be equal (an F-test fails to reject the model that constrains them to be the same). This formulation contains a new interaction term, $\log (1-\mathrm{ETR})^{*}$ Year90s, where Year90s equals unity if the data are from the 
years 1992 or 1994, and equals zero if the data are from 1984. The coefficient on the new interaction term measures the difference between the 1984 tax elasticity (the pre-TRA'86 elasticity) and the tax elasticity for the later sample years (the post-TRA'86 elasticity). We initially included the Year90 dummy variable, but found that the estimated coefficient on this variable was not statistically significantly different from zero. As was the case in our specification in the third column, an F-test could not reject the year dummy, so we dropped this variable from the final specification. ${ }^{39}$ The estimates for the remaining coefficients are similar to those in the third column. The estimated 1984 tax elasticity is about 3.5, and is still statistically significantly different than zero at high levels of confidence; the post-TRA'86 tax elasticity is negative and not statistically significantly different from zero. ${ }^{40}$ The difference between the elasticities is large (about five) and is significant at the one percent level.

Although our estimates suggest that the changes accompanying TRA' 86 have affected the role played by taxes in the location of assets in financial subsidiaries, it is possible that other factors are responsible. One way of attempting to isolate the impact of the tax policy changes is to compare our results to those for the manufacturing industry. As we explained above, the "tightening" of Subpart F should be of much less importance to location of capital generating active manufacturing income (and the results in AGN suggest that in contrast to the results in Table 4, manufacturing capital has become significantly more responsive to effective tax rate differences across countries).

\footnotetext{
39. We also experimented with a specification that drops the GDP variable and includes the Year90 dummy. The resulting tax elasticity estimates were smaller and less statistically significant (3.14 and statistically significant at a six percent confidence level for 1984 and -0.84 and statistically insignificant for the 1990s). As in estimates in the third and fourth columns of Table 4, the difference between the elasticities was large and statistically significantly different from zero (the coefficient on the interaction term was 3.97, and statistically significantly different from zero at a five percent confidence level). The coefficient on the Year90 dummy was 0.80 and was not statistically different from zero at conventional levels. Finally, the adjusted R-squared was similar $(0.83)$ to the specification in the fourth column of Table 4 .

40. Our estimates are the first of which we are aware to measure the responsiveness of capital held in financial subsidiaries to local taxes. Although we have no reason to suspect any serious measurement problems, this makes it difficult to determine whether our elasticity estimates are "reasonable." The estimates presented later in Tables 6 and 7 allow us to compare tax elasticities for total capital held in financial subsidiaries with analogous measures for real capital held in manufacturing subsidiaries for our sample. We compare our elasticity measures for manufacturing capital to others in the literature in our discussion of Table 6.
} 
Before discussing our results for the manufacturing affiliates in our sample, we explore some alternative specifications to test the sensitivity of our results to the measurement of effective tax rates and to the inclusion of countries that may be outliers. In first column of Table 5, for example, we remove countries with small populations (under one million people) that may best be classified as tax havens for financial affiliates. In particular, we deleted Bermuda and Luxembourg from the sample. These exclusions had little impact on our results. The significance of the 1984 tax elasticity and the interaction term decreases slightly but both remain statistically significant at conventional levels. A natural experiment given our hypothesis would be to eliminate all countries which had effective tax rates higher than the U.S. rate in 1992 and 1994. The tightening of the Subpart F rules should have no effect on the choice of investment across high-tax countries. However, only one country in our sample had a higher tax rate than the U.S. rate. ${ }^{41}$ As a result, there is no need to partition the sample by effective tax rates to test our hypothesis.

The remaining experiments address various potential problems with our measure of effective tax rates. One concern is that some of the country tax rates were calculated with data from few CFCs. To explore the role played by these observations in our estimates, we eliminated countries with fewer than six CFCs. These results appear in the second column of Table 5. The point estimate for the 1984 elasticity is about 40 percent smaller and is no longer statistically significantly different than zero. As in our fullsample estimates for this specification, however, the post-1984 elasticity is negative and statistically insignificantly different from zero, and, further, the difference between the elasticities across the time period is statistically significantly different from zero at conventional levels of significance. The results continue to point to a diminished role over time for taxes in the location of assets held in financial subsidiaries.

41. In 1992 the average effective tax rate in Denmark was 38.2 percent. 
A more difficult measurement problem to address in our sample is the possible endogeneity of country average effective tax rates to current investment decisions. In the last two columns of Table 5, we experiment with replacing current effective tax rates with their lagged and future values. These experiments, however, require that we drop a third of our dataset (one year of data). In the third column, we use the 1994 and 1984 data, but substitute 1992 effective tax rates for the 1994 rates. In the fourth column of Table 5, we use the 1992 and 1984 data, but substitute 1994 rates for the 1992 effective tax measures. Neither experiment leads to qualitative differences in our results. ${ }^{42}$ At the same time, using the future tax rates shows an even larger decline in the post-1984 tax elasticity and, unlike in our previous results, the post-1984 elasticity is now statistically significantly different than zero.

Our research strategy is to compare any changes in tax elasticities over our sample period across financial and manufacturing affiliates. As discussed above, AGN provide strong evidence that the allocation of real capital abroad in manufacturing affiliates of manufacturing parents has become more sensitive to differences in host country tax rates. Comparing our results for financial subsidiaries to this work suggests the changes in TRA'86, did, as expected have a differential impact on firms in the FIRE industry. However, because we also have data on the location of real assets in manufacturing affiliates, we can use it to compare more directly the tax elasticity estimates for the two industries over the same sample years (recall that AGN uses data from 1984 and 1992) and model specification.

Table 6 presents results which correct for country fixed effects for our sample of manufacturing affiliates using the same specifications in Table $4 .{ }^{43,44}$ Although our sample includes information for both

\footnotetext{
42. We also compared the results in third and fourth columns of Table 5 to specifications estimated with the same years of data. In particular, we compared the third column estimates with the similar specification that uses only the 1984 and 1992 data and the fourth column estimates with a regression run with the 1984 and 1994 data. The tax elasticity and interaction terms estimated from these "comparison" models were similar in both magnitude and statistical significance to the results reported in third and fourth columns of Table 5.

43. Correcting for country fixed effects generated similar results to those found in AGN. The significance of the difference between the tax elasticities in 1984 and in 1992 and 1994 increased in the fixed-effects model. The magnitude of the point estimates of the tax elasticities decreased, in contrast to AGN. However, similar to AGN, our "no fixed effects" elasticities are not statistically different than our "fixed effects" elasticities.

44. The appendix table presents means and standard deviations of the variables used in these specifications.
} 
1992 and 1994, and is composed of a different set of manufacturing affiliates (those associated with U.S. parents in all industry classifications) and a smaller set of countries (40 versus 58), our results are qualitatively similar to $\mathrm{AGN} .{ }^{45}$ We find that the estimated tax elasticity for manufacturing capital has increased over our time period and that the difference between the two estimates is about unity (and is statistically significantly different from zero).

Finally, Table 7 contains results that constrain the countries in our financial and manufacturing samples to be the same. ${ }^{46}$ This direct comparison reveals the same pattern: While the placement of manufacturing assets has become more responsive to variations in effective tax rates across locations during our time period, the allocation of assets in financial affiliates can no longer be explained by these variations. The results suggest that moving the tax rules for multinational corporations toward capital export neutrality reduces, as intended, the role played by taxes in the location of assets abroad. Further, our estimates show that prior to the Act the total capital held in financial subsidiaries was substantially more sensitive to differences in host country effective tax rates than the real capital held in manufacturing subsidiaries.

\footnotetext{
45. For a variety of reasons, we leave out some of the explanatory variables used by AGN. Unlike AGN, we do not include regional dummies. This is because we add country dummies instead of differencing the data to control for fixed country effects. Including regional dummies in addition to the country dummies makes estimation difficult due to the correlation between the variables. Finally, we do not include a variable to capture variations in trade restrictions across countries. We did not find a measure that reflects changes in trade restrictions over our time period. Our goal is not to reproduce the AGN estimates, but to use our data to compare tax elasticities for assets in manufacturing and financial affiliates abroad. Our preferred estimates of the elasticity of real capital to tax rate differences across jurisdictions are the ones presented in AGN (and Grubert and Mutti, 1997) because they use a larger sample of CFCs and are better able to measure manufacturing capital. 46

- The sample contains all of the countries in our financial sample (see Table 1) with the exception of Uruguay which did not appear in the manufacturing data provided to us.
} 


\section{Conclusions}

The provisions of the Tax Reform Act of 1986 which eliminated deferral of U.S. taxes on financial services income earned abroad offer an opportunity to examine the extent to which anti-deferral rules influence the location of assets held abroad in financial affiliates of U.S. firms. At least two questions are of interest. First, did the 1986 rules decrease the sensitivity of asset location to variation in host-country tax rates? Second, did the effective tax increase on U.S. financial services firms operating in low-tax jurisdictions reduce the market share of U.S. firms in those jurisdictions? The first question addresses the economic efficiency question of capital export neutrality; the second question is concerned more with competitiveness.

This paper focuses on the first question. Using data based on U.S. multinational firms' tax returns for 1984, 1992, and 1994, we find that, while assets of financial services subsidiaries were responsive to cross-jurisdictional variation in effective tax rates prior to TRA'86, that responsiveness disappeared after the passage of the Act. This stands in contrast to the pattern we (and others) estimate for the mobility of capital in manufacturing subsidiaries. Our findings suggest that the Act's provisions achieved the goal of moving the tax treatment of financial services firms closer to capital export neutrality.

Additional research is required to study the second question. The data requirements for such an analysis are significant owing to the need to study market shares in a well-defined financial product or service in a given country or set of countries by multinationals headquartered in the United States and elsewhere. This research will shed light on the cost to U.S. financial services firms of the shift toward capital export neutrality embraced in the 1986 Act. 


\section{References}

Altshuler, Rosanne, Harry Grubert, and T. Scott Newlon. 1998. "Has U.S. investment become more sensitive to tax rates?" NBER Working Paper 6383.

Altshuler, Rosanne and T. Scott Newlon. 1993. "The effects of U.S. tax policy on the income repatriation patterns of U.S. multinational corporations." In Studies in international taxation, ed. A. Giovannini, R.G. Hubbard, and J. Slemrod, 77-115. Chicago: University of Chicago Press.

Cummins, Jason G., and R. Glenn Hubbard. 1995. "The Tax Sensitivity of Foreign Direct Investment: Evidence from Firm-Level Panel Data." in M. Feldstein, J.R. Hines, Jr., and R.G. Hubbard, eds., Effects of Taxation on Multinational Corporations, Chicago: University of Chicago Press.

Dehoff, Michael. 1998. "Budget Agreement Extends - and Broadens - Subpart F Exemption," Tax Notes, November 2.

Desai, Mihir and James R. Hines, Jr. 1999. "'Basket' cases: Tax incentives and international joint venture participation by American multinational firms," Journal of Public Economics 71(3), 379-402.

Dunahoo, Carol, Andrew Lyon, and Peter Merrill, 1997. "International competitiveness of U.S. life insurance companies: Vetoed section 1175 of the Taxpayer Relief Act of 1997," Tax Notes, 176973.

Grubert, Harry. 1997. "Tax planning by companies and tax competition by governments: Is there evidence of changes in behavior?" Mimeograph. Prepared for the NBER Conference on International Taxation held in November 1997.

Grubert, Harry and John Mutti. 1991. "Taxes, tariffs and transfer pricing in multinational corporation decision making." Review of Economics and Statistics 33: 285-293.

Grubert, Harry and John Mutti. 1997. "Do taxes influence where U.S. corporations invest?" Mimeograph U.S. Department of the Treasury.

Grubert, Harry, William Randolph, and Donald Rousslang. 1996. "The response of countries and multinational companies to the Tax Reform Act of 1986." National Tax Journal 49(3): 341-358.

Hines, James R., Jr. 1995. "Forbidden payments: Foreign bribery and American business after 1977." NBER Working Paper 5266.

Hines, James R., Jr. 1997. "Tax policy and the activities of multinational corporations." In Fiscal policy: Lessons from economic research, ed. Alan J. Auerbach. Cambridge: MIT Press.

Hines, James R., Jr. 1999a. "Lessons from Behavioral Responses to International Taxation," National Tax Journal, 52(2), 305-322.

Hines, James R., Jr. 1999b. "The Case Against Deferral: A Deferential Reconsideration," National Tax Journal, 52(3), 385-404. 
Hines, James R., Jr. and R. Glenn Hubbard. 1995. Appendix to Taxing Multinational Corporations. Chicago: University of Chicago Press, 103-106.

Hines, James R., Jr. and Eric M. Rice. 1994. "Fiscal paradise: Foreign tax havens and American business." Quarterly Journal of Economics 109: 149-182.

Horst, Thomas. 1997. The impact of the U.S. tax code on the competitiveness of financial service firms, Washington, D.C.: American Council for Capital Formation.

Hubbard, R. Glenn. 1995. "U.S. tax policy and foreign direct investment: Incentives, problems and reforms.” Washington, D.C.: American Council for Capital Formation.

Hufbauer, Gary. 1992. U.S. taxation of international income: Blueprint for reform. Institute for International Economics, Washington, D.C.

International Monetary Fund. 1984, 1992, and 1994. International Monetary Fund International Financial Statistics. Washington, D.C.: International Monetary Fund.

Latzy, John and Randy Miller. 1992. "Controlled Foreign Corporations, 1988." Statistics of Income Bulletin, Fall 1992, 12(2): 60-70.

National Foreign Trade Council. 1999. The NFTC foreign income project: International tax policy for the $21^{\text {st }}$ century. Washington, D.C.: National Foreign Trade Council.

Organization for Economic Co-operation and Development (OECD). 1996. Controlled Foreign Company Legislation.

Price Waterhouse. 1984, 1992, and 1994. Corporate taxes: A worldwide summary. New York.

Price Waterhouse. 1997. "Decline in the U.S.-controlled share of the open registry merchant shipping fleet since 1975.” June.

PricewaterhouseCoopers. 1998. "Revenue estimating issues related to Subpart F pipeline income." Mimeograph, July.

U.S. Congress, Joint Committee on Taxation. 1987. General explanation of the Tax Reform Act of 1986, U.S. Government Printing Office, Washington, D.C. 
Table 1

Country Effective Tax Rates

for Financial Subsidiaries of U.S. MNCs

\begin{tabular}{|c|c|c|}
\hline & 1984 & $1990 \mathrm{~s}$ \\
\hline Argentina & 0.226 & 0.172 \\
\hline Australia & 0.207 & 0.160 \\
\hline Austria & 0.032 & 0.100 \\
\hline Belgium & 0.363 & 0.054 \\
\hline Bermuda & 0.015 & 0.036 \\
\hline Brazil & 0.270 & 0.118 \\
\hline Canada & 0.214 & 0.193 \\
\hline Chile & 0.404 & 0.097 \\
\hline Colombia & 0.476 & 0.242 \\
\hline Denmark & 0.215 & 0.240 \\
\hline France & 0.275 & 0.112 \\
\hline Greece & 0.057 & 0.233 \\
\hline Hong Kong & 0.079 & 0.131 \\
\hline Ireland & 0.101 & 0.026 \\
\hline Italy & 0.368 & 0.268 \\
\hline Japan & 0.490 & 0.126 \\
\hline Luxembourg & 0.242 & 0.040 \\
\hline Malaysia & 0.325 & 0.165 \\
\hline Mexico & 0.177 & 0.155 \\
\hline Netherlands & 0.109 & 0.057 \\
\hline Norway & 0.629 & 0.108 \\
\hline Panama & 0.019 & 0.098 \\
\hline Philippines & 0.450 & 0.133 \\
\hline Singapore & 0.231 & 0.076 \\
\hline Spain & 0.312 & 0.144 \\
\hline Sweden & 0.030 & 0.092 \\
\hline Switzerland & 0.136 & 0.107 \\
\hline Thailand & 0.256 & 0.258 \\
\hline United Kingdom & 0.201 & 0.105 \\
\hline Uruguay & 0.353 & 0.055 \\
\hline Venezuela & 0.272 & 0.004 \\
\hline West Germany & 0.305 & 0.207 \\
\hline Average & 0.245 & 0.129 \\
\hline Standard Deviation & 0.151 & 0.071 \\
\hline
\end{tabular}

Note: The table reports country average effective tax rates for financial subsidiaries of U.S. multinational corporations. The third column gives the average of the 1992 and 1994 effective tax rates for each country. Average effective tax rates in each country are calculated by dividing the total income taxes paid by controlled foreign corporations in the financial sector by their total earnings and profits. Information on the total income taxes paid and earnings and profits comes from tax return information reported on the Form 5471 and provided by the Internal Revenue Service. 
Table 2

Country Effective Tax Rates

for Manufacturing Subsidiaries of U.S. MNCs

\begin{tabular}{|c|c|c|}
\hline & 1984 & $1990 \mathrm{~s}$ \\
\hline Argentina & 0.015 & 0.175 \\
\hline Australia & 0.408 & 0.257 \\
\hline Austria & 0.392 & 0.272 \\
\hline Belgium & 0.376 & 0.233 \\
\hline Bermuda & 0.033 & 0.071 \\
\hline Brazil & 0.308 & 0.140 \\
\hline Canada & 0.370 & 0.316 \\
\hline Chile & 0.380 & 0.104 \\
\hline China & 0.164 & 0.081 \\
\hline Colombia & 0.345 & 0.293 \\
\hline Denmark & 0.380 & 0.361 \\
\hline Finland & 0.433 & 0.102 \\
\hline France & 0.437 & 0.218 \\
\hline Greece & 0.356 & 0.325 \\
\hline Hong Kong & 0.199 & 0.089 \\
\hline India & 0.576 & 0.385 \\
\hline Ireland & 0.026 & 0.070 \\
\hline Israel & 0.099 & 0.138 \\
\hline Italy & 0.375 & 0.298 \\
\hline Japan & 0.529 & 0.479 \\
\hline Luxembourg & 0.496 & 0.237 \\
\hline Malaysia & 0.174 & 0.058 \\
\hline Mexico & 0.554 & 0.254 \\
\hline Netherlands & 0.197 & 0.170 \\
\hline New Zealand & 0.470 & 0.278 \\
\hline Norway & 0.375 & 0.330 \\
\hline Panama & 0.260 & 0.084 \\
\hline Philippines & 0.367 & 0.349 \\
\hline Portugal & 0.244 & 0.250 \\
\hline Singapore & 0.082 & 0.043 \\
\hline South Africa & 0.512 & 0.398 \\
\hline South Korea & 0.206 & 0.265 \\
\hline Spain & 0.285 & 0.223 \\
\hline Sweden & 0.575 & 0.154 \\
\hline Switzerland & 0.202 & 0.115 \\
\hline Thailand & 0.320 & 0.162 \\
\hline Turkey & 0.450 & 0.467 \\
\hline United Kingdom & 0.330 & 0.206 \\
\hline Venezuela & 0.339 & 0.187 \\
\hline West Germany & 0.504 & 0.242 \\
\hline Average & 0.329 & 0.222 \\
\hline Standard Deviation & 0.151 & 0.119 \\
\hline
\end{tabular}

Note: The table reports country average effective tax rates for manufacturing subsidiaries of U.S. multinational corporations. The third column gives the average of the 1992 and 1994 effective tax rates for each country. Average effective tax rates in each country are calculated by dividing the total income taxes paid by controlled foreign corporations in the manufacturing sector by their total earnings and profits. Information on the total income taxes paid and earnings and profits comes from tax return information reported on the Form 5471 and provided by the Internal Revenue Service. 
Table 3

Ratio of Real Assets to Total Assets for Financial and Manufacturing Subsidiaries of U.S. MNCs

\begin{tabular}{|c|c|c|}
\hline & \multicolumn{2}{|c|}{ Average over 1984, 1992, and 1994 data } \\
\hline & $\begin{array}{c}\text { Financial } \\
\text { subsidiaries }\end{array}$ & $\begin{array}{c}\text { Manufacturing } \\
\text { subsidiaries }\end{array}$ \\
\hline Argentina & 0.084 & 0.758 \\
\hline Australia & 0.052 & 0.793 \\
\hline Austria & 0.079 & 0.638 \\
\hline Belgium & 0.024 & 0.635 \\
\hline Bermuda & 0.053 & 0.210 \\
\hline Brazil & 0.062 & 0.703 \\
\hline Canada & 0.056 & 0.634 \\
\hline Chile & 0.039 & 0.644 \\
\hline China & na & 0.622 \\
\hline Colombia & 0.098 & 0.577 \\
\hline Denmark & 0.110 & 0.519 \\
\hline Finland & na & 0.528 \\
\hline France & 0.182 & 0.679 \\
\hline Greece & 0.037 & 0.537 \\
\hline Hong Kong & 0.260 & 0.275 \\
\hline India & na & 0.727 \\
\hline Ireland & 0.076 & 0.291 \\
\hline Israel & na & 0.606 \\
\hline Italy & 0.079 & 0.515 \\
\hline Japan & 0.117 & 0.628 \\
\hline Luxembourg & 0.019 & 0.908 \\
\hline Malaysia & 0.010 & 0.775 \\
\hline Mexico & 0.114 & 0.668 \\
\hline Netherlands & 0.042 & 0.705 \\
\hline New Zealand & na & 0.798 \\
\hline Norway & 0.164 & 0.748 \\
\hline Panama & 0.015 & 0.212 \\
\hline Philippines & 0.040 & 0.678 \\
\hline Portugal & na & 0.621 \\
\hline Singapore & 0.027 & 0.608 \\
\hline South Africa & na & 0.632 \\
\hline South Korea & na & 0.587 \\
\hline Spain & 0.038 & 0.738 \\
\hline Sweden & 0.029 & 0.694 \\
\hline Switzerland & 0.095 & 0.353 \\
\hline Thailand & 0.018 & 0.729 \\
\hline Turkey & na & 0.787 \\
\hline United Kingdom & 0.200 & 0.685 \\
\hline Uruguay & 0.043 & na \\
\hline Venezuela & 0.030 & 0.597 \\
\hline West Germany & 0.131 & 0.829 \\
\hline Average & 0.076 & 0.622 \\
\hline
\end{tabular}

Note: The table reports the ratio of real assets to total assets held in financial and manufacturing subsidiaries, respectively, of U.S. multinational corporations averaged over the years 1984, 1992, and 1994. Information on real and total assets comes from tax return information reported on the Form 5471 and provided by the Internal Revenue Service. 
Table 4

Taxes and the Location of Assets Held Abroad in

Financial Subsidiaries of U.S. Corporations

\begin{tabular}{|c|c|c|c|c|}
\hline & \multicolumn{4}{|c|}{ Dependent variable $=\log$ of total assets } \\
\hline & $(1)$ & (2) & (3) & $(4)$ \\
\hline Constant & $\begin{array}{l}20.08 \\
(1.09)\end{array}$ & $\begin{array}{l}20.54 \\
(1.94)\end{array}$ & $\begin{array}{c}18.41 \\
(1.44)\end{array}$ & $\begin{array}{c}18.34 \\
(1.43)\end{array}$ \\
\hline $\log (1-E T R)$ & $\begin{array}{c}6.49 \\
(2.99)\end{array}$ & $\begin{array}{c}3.16 \\
(1.71)\end{array}$ & $\begin{array}{c}3.64 \\
(1.45)\end{array}$ & $\begin{array}{c}3.53 \\
(1.43)\end{array}$ \\
\hline $\log (\mathrm{GDP})$ & $\begin{array}{c}0.58 \\
(0.14)\end{array}$ & $\begin{array}{c}0.05 \\
(0.53)\end{array}$ & $\begin{array}{c}0.62 \\
(0.29)\end{array}$ & $\begin{array}{c}0.63 \\
(0.29)\end{array}$ \\
\hline Log(1-ETR)*Year92 & $\begin{array}{c}1.41 \\
(4.16)\end{array}$ & $\begin{array}{l}-4.08 \\
(2.35)\end{array}$ & $\begin{array}{c}-4.33 \\
(1.35)\end{array}$ & \\
\hline $\log (1-E T R) * Y e a r 94$ & $\begin{array}{c}0.38 \\
(3.70)\end{array}$ & $\begin{array}{l}-3.61 \\
(2.04)\end{array}$ & $\begin{array}{l}-5.28 \\
(1.50)\end{array}$ & \\
\hline Log(1-ETR)*Year90s & & & & $\begin{array}{l}-4.98 \\
(1.39)\end{array}$ \\
\hline Year92 & $\begin{array}{c}0.45 \\
(1.11)\end{array}$ & $\begin{array}{c}0.60 \\
(0.83)\end{array}$ & & \\
\hline Year94 & $\begin{array}{c}0.68 \\
(1.09)\end{array}$ & $\begin{array}{c}0.96 \\
(0.81)\end{array}$ & & \\
\hline Country dummies? & No & Yes & Yes & Yes \\
\hline Adjusted R squared & 0.34 & 0.83 & 0.83 & 0.83 \\
\hline Number of observations & 96 & 96 & 96 & 96 \\
\hline \multicolumn{5}{|c|}{ Tax elasticities By Year } \\
\hline 1984 & $\begin{array}{c}6.49 \\
(2.99)\end{array}$ & $\begin{array}{c}3.16 \\
(1.71)\end{array}$ & $\begin{array}{c}3.64 \\
(1.45)\end{array}$ & $\begin{array}{c}3.53 \\
(1.43)\end{array}$ \\
\hline 1992 & $\begin{array}{c}7.90 \\
(2.96)\end{array}$ & $\begin{array}{l}-0.92 \\
(1.44)\end{array}$ & $\begin{array}{l}-0.70 \\
(1.71)\end{array}$ & \\
\hline 1994 & $\begin{array}{c}6.87 \\
(2.22)\end{array}$ & $\begin{array}{l}-0.45 \\
(1.47)\end{array}$ & $\begin{array}{l}-1.64 \\
(1.58)\end{array}$ & \\
\hline $1990 \mathrm{~s}$ & & & & $\begin{array}{l}-1.44 \\
(1.55)\end{array}$ \\
\hline Country dummies? & No & Yes & Yes & Yes \\
\hline
\end{tabular}

Note: ETR is equal to the country average effective tax rate. The dummy variables Year92 and Year94 equal one for 1992 and 1994, respectively. The dummy variable Year90s equals one for 1992 and 1994. The columns report coefficients estimated using OLS. The bottom panel reports tax elasticity estimates from each regression. White-corrected standard errors are in 
Table 5

Alternative Specifications of the Financial Services Regressions

\begin{tabular}{lcccc}
\hline \hline & \multicolumn{4}{c}{ Dependent variable $=$ log of total assets } \\
\cline { 2 - 5 } & $\begin{array}{c}\text { Remove countries } \\
\text { with small populations }\end{array}$ & $\begin{array}{c}\text { Remove countries } \\
\text { with few CFCs }\end{array}$ & $\begin{array}{c}\text { Use lagged values } \\
\text { of ETRs }\end{array}$ & $\begin{array}{c}\text { Use future values } \\
\text { of ETRs }\end{array}$ \\
\hline Constant & 17.79 & 16.64 & 18.10 & 19.94 \\
& $(1.52)$ & $(1.68)$ & $(1.49)$ & $(1.36)$ \\
$\log (1-\mathrm{ETR})$ & 3.48 & 1.48 & 3.96 & 3.31 \\
& $(1.45)$ & $(1.53)$ & $(1.51)$ & $(1.38)$ \\
$\log (\mathrm{GDP})$ & 0.77 & 0.95 & 0.78 & 0.17 \\
& $(0.31)$ & $(0.34)$ & $(0.31)$ & $(0.25)$ \\
$\log (1-\mathrm{ETR}) *$ Year90s & -4.49 & -3.29 & -4.14 & -6.76 \\
& $(1.46)$ & $(1.67)$ & $(1.85)$ & $(1.03)$ \\
Country dummies? & Yes & Yes & 0.78 & Yes \\
\hline Adjusted R squared & 0.83 & 0.80 & 64 & 0.80 \\
Number of observations & 90 & 84 & & 64 \\
\hline \hline
\end{tabular}

\begin{tabular}{ccccc}
\multicolumn{5}{c}{ Tax elasticities By Year } \\
\hline \hline \multirow{2}{*}{1984} & 3.48 & 1.48 & 3.96 & 3.31 \\
& $(1.82)$ & $(1.53)$ & $(1.51)$ & $(1.38)$ \\
$1990 \mathrm{~s}$ & -1.01 & -1.89 & -0.18 & -3.45 \\
& $(1.60)$ & $(1.65)$ & $(2.17)$ & $(1.26)$ \\
Country dummies? & Yes & Yes & Yes & Yes \\
\hline \hline
\end{tabular}

Note: The first column excludes countries with populations of less than one million people. The second column excludes countries with fewer than six CFCs in any year of the sample period. The third column uses data from 1984 and 1994, but replaces ETR in 1994 with country average effective tax rates calculated from 1992 data. The fourth column uses data from 1984 and 1992, but replaces ETR in 1992 with country average effective tax rates calculated from 1994 data. The columns report estimated coefficients estimated using OLS. White-corrected standard errors are in parentheses. See the notes to Table 4 for variable definitions. 
Table 6

Taxes and the Location of Real Assets Held Abroad in Manufacturing Subsidiaries of U.S. Corporations

\begin{tabular}{lccc}
\hline \hline & \multicolumn{3}{c}{ Dependent variable $=$ log of real assets } \\
\cline { 2 - 4 } Constant & $(1)$ & $(2)$ & $(3)$ \\
\hline \multirow{2}{*}{ Log(1-ETR) } & $(0.14)$ & 19.59 & 19.59 \\
& 0.11 & $(0.11)$ & $(0.11)$ \\
Log (GDP) & $(0.31)$ & 0.18 & 0.17 \\
& 1.11 & $1.29)$ & $(0.29)$ \\
Log(1-ETR)*Year92 & $(0.15)$ & $(0.10)$ & 1.17 \\
& 1.02 & 0.99 & \\
Log(1-ETR)*Year94 & $(0.42)$ & $(0.36)$ & \\
& 1.18 & 1.01 & 0.99 \\
Log(1-ETR)*Year90s & $(0.40)$ & $(0.40)$ & $(0.36)$ \\
Year92 & & & \\
Year94 & & & \\
Country dummies? & 0.07 & & Yes \\
\hline Adjusted R squared & $(0.14)$ & Yes & 0.97 \\
Number of observations & 0.13 & 0.97 & 120 \\
\hline \hline
\end{tabular}

Tax elasticities By Year

\begin{tabular}{cccc}
\hline \hline 1984 & 0.11 & 0.18 & 0.17 \\
& $(0.31)$ & $(0.29)$ & $(0.29)$ \\
1992 & 1.13 & 1.17 & \\
& $(0.55)$ & $(0.51)$ & \\
1994 & 1.29 & 1.19 & 1.17 \\
& $(0.55)$ & $(0.55)$ & $(0.50)$ \\
$1990 \mathrm{~s}$ & & & Yes \\
\hline \hline
\end{tabular}

Note: The columns report coefficients estimated using OLS. The bottom panel reports tax elasticity estimates from each regression. White-corrected standard errors are in parentheses. See the notes to Table 4 for variable definitions. 
Table 7

Comparison of Results for Financial and

Manufacturing Subsidaries of U.S. MNCs

\begin{tabular}{lcc}
\hline \hline & $\begin{array}{c}\text { Financial } \\
\text { subsidiaries }\end{array}$ & $\begin{array}{c}\text { Manufacturing } \\
\text { subsidiaries }\end{array}$ \\
\hline Constant & 18.37 & 19.62 \\
Log(1-ETR) & $(1.42)$ & $(0.14)$ \\
& 3.57 & 0.33 \\
Log (GDP) & $(1.45)$ & $(0.34)$ \\
Log(1-ETR)*Year90s & 0.63 & 0.99 \\
& $(0.29)$ & $(0.09)$ \\
Country dummies? & -4.97 & 0.51 \\
\hline Adjusted R squared & $(1.39)$ & $(0.24)$ \\
Number of observations & Yes & Yes \\
\hline \hline
\end{tabular}

Tax Elasticities by Year

\begin{tabular}{ccc}
\hline \hline \multirow{2}{*}{1984} & 3.57 & 0.33 \\
& $(1.45)$ & $(0.34)$ \\
$1990 \mathrm{~s}$ & -1.40 & 0.84 \\
& $(1.59)$ & $(0.42)$ \\
Country dummies? & Yes & Yes \\
\hline \hline
\end{tabular}

Note: The same sample of 31 countries is used to produce the estimates reported in the two columns of the table. The dependent variable for the financial subsidiaries regression is the log of total assets. The dependent variable for the manufacturing subsidiaries regression is the $\log$ of real assets. The columns report coefficients estimated using OLS. White-corrected standard errors are in parentheses. See the notes to Table 4 for variable definitions. 


\section{Appendix Table \\ Variable Means and Standard Deviations}

Financial Subsidiaries of U.S. MNCs

\begin{tabular}{lccc}
\multicolumn{3}{c}{$(32$ countries $)$} & \\
\hline \hline Log(Total assets $)$ & $\begin{array}{c}\text { Number of } \\
\text { observations }\end{array}$ & Mean & $\begin{array}{c}\text { Standard } \\
\text { Deviation }\end{array}$ \\
\hline $\log (1-\mathrm{ETR})$ & 96 & 21.887 & 2.220 \\
$\log (\mathrm{GDP})$ & 96 & -0.191 & 0.143 \\
$\log (1-\mathrm{ETR}) *$ Year84 & 96 & 4.722 & 1.686 \\
$\log (1-\mathrm{ETR}) *$ Year92 & 96 & -0.092 & 0.167 \\
$\log (1-\mathrm{ETR}) *$ Year94 & 96 & -0.046 & 0.080 \\
$\log (1-\mathrm{ETR}) *$ Year90s & 96 & -0.052 & 0.097 \\
\hline \hline
\end{tabular}

Manufacturing Subsidiaries of U.S. MNCs

(40 countries)

\begin{tabular}{lccc}
\hline \hline & $\begin{array}{c}\text { Number of } \\
\text { observations }\end{array}$ & Mean & $\begin{array}{c}\text { Standard } \\
\text { Deviation }\end{array}$ \\
\hline $\log ($ Real assets $)$ & 120 & 21.400 & 1.611 \\
$\log (1-\mathrm{ETR})$ & 120 & -0.301 & 0.184 \\
$\log (\mathrm{GDP})$ & 120 & 4.773 & 1.515 \\
$\log (1-\mathrm{ETR}) *$ Year84 & 120 & -0.134 & 0.226 \\
$\log (1-\mathrm{ETR}) *$ Year92 & 120 & -0.088 & 0.153 \\
$\log (1-\mathrm{ETR}) *$ Year94 & 120 & -0.079 & 0.136 \\
$\log (1-\mathrm{ETR}) *$ Year90s & 120 & -0.168 & 0.167 \\
\hline \hline
\end{tabular}

Source: International Monetary Fund (1984, 1992, 1994) and Internal Revenue Service. 